\title{
OPTIMALISASI IMPLEMENTASI PERATURAN BEBAS ROKOK DI DALAM RUMAH
}

\author{
Machfudloh $^{1}$, Ike Lorna Sulbani ${ }^{2}$ \\ 1,2Prodi DIII Kebidanan, FK Unissula Semarang

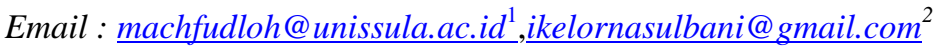

\begin{abstract}
ABSTRAK
Indonesia menduduki peringkat ke-5 konsumen rokok terbesarduniaPada tahun 2007 dan hasil Riskesdas menyebutkan bahwa penduduk berumur di atas 10 tahun yang merokok sebesar 29,2\% dan angka tersebut meningkat sebesar 34,7\% pada tahun 2010 untuk kelompok umur diatas 15 tahun. Selain menyebabkan gangguan kesehatan pada perokok aktif, asap rokok juga berbahaya untuk perokok pasif terutama ibu hamil. Penelitian ini bertujuan untuk mengetahui hambatan dalam melakukan implementasi peraturan bebas rokok didalam rumah berdasarkan PP No. 19, 2003 dan berdasarkan UU No. 36 Tahun 2009. Rancangan penelitian yang digunakan adalah deskriptif analisis melalui pendekatan crosssectional. Metodenya dengan penggabungan dari studi literatur, pengamatan, wawancara dan menggunakan analisis statistika deskriptif. Sampel dalam penelitian ini adalah kepala keluarga yang merokok, tokoh agama, tokoh masyarakat, dan tenaga kesehatan di Desa Gaji Guntur Demak dengan tehnik purposive sampling berjumlah 49 responden. Hasil penelitian adalahsebagian besar pengetahuan tentang rokok sebanyak $44,2 \%$ tergolong sedang.Perilaku masyarakat terhadap merokok tergolong tinggi sebesar 76,8. Faktor Pemungkin97,9\% toko menjual rokok secara bebas dan $91,6 \%$ jarak rumah warga dengan toko penjual rokok $\leq 2 \mathrm{~km}$. Faktor Penguat bahwa; $100 \%$ teman merokok, 97,9\% tokoh masyarakat merokok, 96,8\% pemuka agama merokok, 96,8\% disediakan rokok saat ada acara (hajatan), $77,9 \%$ orang tua merokok dan $46,3 \%$ masyarakat menganggap iklan rokok menarik.
\end{abstract}

\section{Kata Kunci : Rokok; Peraturan bebas rokok didalam rumah}

\section{OPTIMIZATION OF FREE CIGARETTE REGULATION IMPLEMENTATION IN HOUSES}

\begin{abstract}
Indonesia is the big fifth cigarette consumers. The results of Riskesdas stated that the population aged over 10 years who smoked was $29.2 \%$ and that number increased by $34.7 \%$ in 2010 for the age group above 15 years. Cigarette smoke is also dangerous for passive smokers, especially pregnant women. This study aim was to determine the barriers to implementing smoke-free regulations at home according to Government Regulation No. 19, 2003 and based on Law No. 36 of 2009. The research design used was descriptive analysis through a cross sectional approach. The method is by combining literature studies, observations, interviews and using descriptive statistical analysis. The samples in this study were smokers such as family heads, religious leaders, community leaders, and health workers in Gaji Guntur Demak Village with purposive sampling techniques totaling 49 respondents. The results of the study are mostly knowledge about cigarettes as much as $44.2 \%$ classified as moderate. Community behavior towards smoking is classified as high at 76.8. The Enabling Factor.99\% of free cigarettes seller and $91.6 \%$ of the distance between residents' houses and cigarette shops is $2 \mathrm{~km}$. Strengthening factors showed $100 \%$ of friends smoke, $97.9 \%$ of community leaders smoke, $96.8 \%$ of religious leaders smoke, 96.8\% are provided with cigarettes when there is an event (celebration), $77.9 \%$ of parents smoke and $46.3 \%$ the community considers cigarette advertising attractive.
\end{abstract}

Keywords: Cigarettes, Home free from cigarettes, smoking regulations 


\section{Pendahuluan}

Merokok merupakan salah satu masalah kesehatan masyarakat di Indonesia karena merokok merupakan faktor risiko utama dari beberapa penyakit kronis seperti kanker paruparu, kanker saluran pernafasan bagian atas, penyakit jantung, stroke, bronkhitis, emphysema dan lain-lain, bahkan merokok ini dapat menyebabkan kematian (Sirait dkk, 2002). Rokok merupakan salah satu penyebab kematian terbesar di dunia. Diperkirakan hingga menjelang 2030 kematian akibat merokok akan mencapai 10 juta per tahunnya dan di negara-negara berkembang diperkirakan tidak kurang $70 \%$ kematian yang disebabkan oleh rokok (Kemenkes, 2011).

Indonesia menduduki peringkat ke-5 konsumen rokok terbesar setelah China, Amerika Serikat, Rusia dan Jepang Pada tahun 2007 (WHO, 2008). Pada tahun yang sama, Riset Kesehatan Dasar menyebutkan bahwa penduduk berumur di atas 10 tahun yang merokok sebesar 29,2\% dan angka tersebut meningkat sebesar 34,7\% pada tahun 2010 untuk kelompok umur di atas 15 tahun. Selain menyebabkan gangguan kesehatan pada perokok aktif, asap rokok juga berbahaya untuk perokok pasif terutama ibu hamil.

Paparan asap rokok dapat menyebabkan BBLR (Berat Badan Bayi Lahir Rendah) hal ini dikarenakan menurunnya aliran darah umbilikal yang akhirnya menyebabkan gangguan pertumbuhan pada janin sehingga menyebabkan bayi berat lahir rendah (BBLR) (Hanum dan Wibowo, 2016). Hal ini sesuai dengan penelitian Sutrisno dan Syiska (2013) bahwa semakin lama ibu hamil bersama perokok aktif di dalam rumah dengan rata-rata ibu terpapar asap rokok $>7$ jam setiap harinya, maka risiko melahirkan bayi dengan berat badan lahir rendah semakin tinggi. Ibu hamil perokok pasif yang terpapar asap rokok 1-10 batang per hari berisiko 2,4 kali lebih sering untuk terjadinya bayi berat lahir rendah (BBLR).

Visi terwujudnya "Masyarakat Demak yang Semakin Sehat dan Mandiri”ditunjukkan dengan suatu indikator status kesehatan, yaitu umur harapan hidup waktu lahir, angka kematian, angka status gizi dan angka kesakitan. Persentase rumah sehat di Kabupaten Demak di tahun 2015 mencapai 51,66 \% atau 164.982 dari total jumlah rumah sebanyak 319.343 persentase rumah sehat tahun 2012-2015. Pada data Kecamatan Guntur sendiri, pada tahun 2015 persentase rumah sehat sebesar 63,42\% (Profil Kesehatan Kabupaten Demak, 2015). 


\section{Tinjauan Teoritis}

\section{Peraturan Pemerintah Indonesia tentang rokok}

Rokok adalah produk tembakau yangpenggunaannya dengan cara dibakar dan dihisap asapnya dan/atau dihirupasapnya yang dihasilkan dari tanaman Nicotiana tabacum, Nicotiniarustica, dan spesies lainnya atau sintesisnya yang asapnya mengandungnikotin dan tar dengan atau tanpa bahan tambahan (PP RI Nomor 109 Tahun 2012).

Pemerintah mengatur tempat umum, sarana kesehatan, tempat kerja, dan tempat yang secara spesifik sebagai proses belajar mengajar, arena kegiatan anak, tempat ibadah, dan angkutan umum dinyatakan sebagai kawasan tanpa rokok. Hal ini diatur dalam peraturan pemerintah republik indonesia nomor 19 tahun 2003 tentang pengaman rokok bagi kesehatan (PP No. 19, 2003).

Undang Undang Nomor 36 Tahun 2009 Tentang Kesehatan, juga mencantumkan peraturan Kawasan Tanpa Rokok pada Bagian Ketujuh Belas, Pengamanan Zat Adiktif, Pasal 115 ayat ( 1 ) Kawasan tanpa rokok antara lain fasilitas pelayanan kesehatan, tempat proses belajar mengajar, tempat anak bermain, tempat ibadah, angkutan umum, tempat kerja, dan tempat umum dan tempat lain yang ditetapkan (UU No.36, 2009).

\section{Pengaruh rokok terhadap Kesehatan Keluarga}

Asap tembakau mengandung lebih dari 7.000 bahan kimia yang ratusannya merupakan zat beracun. Dampak dari asap rokok tidak hanya dirasakan perokok sendiri (perokok aktif), tetapi juga orang yang berada di lingkungan asap rokok (environmental tobacco smoke) atau disebut dengan perokok pasif. Pengaruh rokok terhadap kehamilan sangat serius. Rokok dapat mengurangi aliran darah ke plasenta sehingga berisiko menimbulkan gangguan pertumbuhan janin. Rokok juga dapat meningkatkan risiko keguguran, berat badan bayi rendah, dan gangguan saluran pada nafas bayi (Hanum, 2015).

Asap rokok sendiri juga mengandung komponen lain yang berbahaya bagi ibu hamil yaitu karbon monoksida (CO) dan nikotin. Jika ibu terpapar nikotin, nikotin akan menyebabkan perangsangan terhadap hormon katekolamin (adrenalin) yang bersifat memacu jantung dan tekanan darah. Jantung tidak diberikan kesempatan istirahat dan tekanan darah akan semakin tinggi, yang mengakibatkan timbulnya hipertensi.

Hal ini dapat mengubah denyut jantung dan aliran darah umbilikal, dan menginduksi hipoksia pada janin. Karbon monoksida dari rokok yang terisap oleh ibu hamil akan terbawa ke aliran darah ibu. Hipoksia pada janin dan menurunnya aliran darah umbilikal sehingga 
menurunkan penerimaan nutrisi bayi sehingga dapat menyebabkan gangguan pertumbuhan pada janin sehingga menyebabkan bayi berat lahir rendah (BBLR) (Hayva, 2013).

\section{Metode Penelitian}

Rancangan penelitian yang digunakan adalah deskriptif analisis dengan memfokuskan pada identifikasi yang mendalam tentang optimalisasi model implementasi kebijakan bebas merokok didalam rumah melalui pendekatan cross sectional. Penelitian dilaksanakan pada bulan Maret s/d April 2018. Metodenya dengan penggabungan dari studi literatur, pengamatan danwawancara, dengan menggunakan analisis statistika deskriptif. Sampel dalam penelitian ini adalah kepala keluarga yang merokok, tokoh agama, tokoh masyarakat, dan tenaga kesehatan di Desa Gaji Kecamatan Guntur Kabupaten Demak. Pemilihan sampel menggunakan non probabilitas dengan tehnik purposive sampling yaitu di RW I yang berjumlah 49 responden.

\section{Hasil Penelitian}

Hasil penelitian ini merupakan hasil wawancara dan pembagian kuesioner kepada kepala keluarga yang merokok, tokoh agama dan tokoh masyarakat. Adapun hasil penelitian yang telah didapat adalah sebagai berikut:

\section{Pengetahuan}

Gambaran pengetahuan responden tentang rokok dapat dilihat pada tabel berikut ini:

Tabel 1. Pengetahuan tentang Rokok

\begin{tabular}{ccc}
\hline Pengetahuan tentang rokok & Jumlah & Persentase \\
\hline Kurang & 21 & 44,2 \\
Cukup & 11 & 23,2 \\
Baik & 17 & 32,6 \\
\hline Total & 49 & 100
\end{tabular}

Gambaran perilaku merokok responden yang dilihat dari aspek : dari intensitas, waktu, sampai jumlah rokok yang dihisap setiap haridapat dilihat pada tabel berikut ini: 
Tabel 2. Perilaku Merokok

\begin{tabular}{ccc}
\hline Perilaku Merokok & Jumlah & Persentase \\
\hline Tinggi & 38 & 76,8 \\
Sedang & 7 & 14,29 \\
Rendah & 4 & 8,91 \\
\hline Total & 49 & 100 \\
\hline
\end{tabular}

\section{Sarana dan Prasarana}

Gambaran sarana dan prasarana dapat dilihat pada tabel berikut ini:

Tabel 3. Sarana Prasarana

\begin{tabular}{lcc}
\hline Sarana dan Prasarana & Jumlah & Persentase \\
\hline Mendukung & 45 & $91,8 \%$ \\
Tidak Mendukung & 4 & $8,2 \%$ \\
\hline Total & 49 & 100.0 \\
\hline
\end{tabular}

\section{Faktor Pemungkin}

Faktor pemungkin (EnablingFactor) yang mempengaruhi responden mempunyai perilaku merokok tinggi dapat dilihat pada tabel berikut:

Tabel 4. Faktor Pemungkin

\begin{tabular}{clc}
\hline No & Faktor pemungkin & Persentase \\
\hline 1 & toko menjual rokok secara bebas & $97,9 \%$ \\
\hline 2 & jarak rumah warga dengan toko penjual rokok $\leq 2 \mathrm{~km}$ & $91,6 \%$
\end{tabular}

\section{Faktor Penguat}

Faktor Penguat (Reinforcing Faktor) yang mempengaruhi responden mempunyai perilaku merokok tinggi dapat dilihat pada tabel berikut:

Tabel 5. Faktor Penguat

\begin{tabular}{clc}
\hline No & Faktor Penguat & Persentase \\
\hline 1 & Teman merokok & $100 \%$ \\
\hline 2 & Tokoh masyarakat merokok & $97,9 \%$ \\
\hline 3 & Pemuka agama merokok & $96,8 \%$, \\
\hline 4 & Disediakan rokok saat ada acara (hajatan) & $96,8 \%$ \\
\hline 5 & Orang tua merokok & $77,9 \%$ \\
\hline 6 & Masyarakat menganggap iklan rokok menarik & $46,3 \%$
\end{tabular}




\section{Pembahasan}

Hasil penelitianmenunjukkan bahwa pengetahuan mengenai merokok pada masyarakat RW I, Desa Gaji, Kecamatan Guntur, Kabupaten Demak sebanyak 44,2\% tergolong sedang dan 23,2\% tergolong rendah. Hal ini menunjukkan masyarakat RW I, Desa Gaji, Kecamatan Guntur, Kabupaten Demak memiliki pengetahuan yang rata - rata masih kurang, misalnya tentang kandungan zat di dalam rokok, bahaya rokok bagi kesehatan, perbedaan perokok aktif dan pasif,dll. Dari faktor perilaku menunjukkan bahwa perilaku masyarakat terhadap merokok tergolong tinggi, yaitu sebesar 76,8 \% yang menandakan kegiatan merokok yang terlihat, baik dari intensitas, waktu, sampai jumlah rokok yang dihisap setiap hari.

Menurut teori Lawrance Green dan kawan-kawan (1980) menyatakan bahwa perilaku manusia dipengaruhi oleh dua faktor pokok, yaitu faktor perilaku (behaviourcauses) dan faktor diluar perilaku (non behaviour causes). Selanjutnya perilaku itu sendiri ditentukan atau terbentuk dari 3 faktor yaitu:Perilaku pada dasarnya berorientasi pada tujuan. Dengan perkataan lain, perilaku kita pada umumnya dimotivasi oleh suatu keinginan untuk mencapai tujuan tertentu. Tujuan spesifik tersebut tidak selalu diketahui secara sadar oleh individu yang bersangkutan (Halifah 2012).

Promosi kesehatan sebagai pendekatan kesehatan terhadap faktor perilaku kesehatan, maka kegiatannya tidak terlepas dari faktor-faktor yang menentukan perilaku tersebut. Dengan perkataan lain, kegiatan promosi kesehatan harus disesuaikan dengan determinan (faktor yang mempengaruhi perilaku itu sendiri). Dan menurut Lawrence Green perilaku ini ditentukan oleh 3 faktor utama, yakni:Faktor predisposisi (predisposing factors), yang mencakup pengetahuan, sikap dan sebagainya.Faktor pemungkin (enabling factor), yang mencakup lingkungan fisik, tersedia atau tidak tersedianya fasilitas-fasilitas atau saranasarana keselamatan kerja, misalnya ketersedianya APD, pelatihan dan sebagainya.Faktor penguat (reinforcement factor), faktor-faktor ini meliputi undang-undang, peraturanperaturan, pengawasan dan sebagainya (Halifah 2012).

Faktor Pemungkin (EnablingFactor) yang mempengaruhi responden mempunyai perilaku tinggi pada penelitian ini menunjukkan bahwa 91,6 \% jarak rumah warga dengan toko penjual rokok $\leq 2 \mathrm{~km}$ dan $97,9 \%$ toko menjual rokok secara bebas.

Faktor Penguat (Reinforcing Factor) pada penelitian ini menunjukkan bahwa 97,9 \% tokoh masyarakat desa merokok, 96,8 \% pemuka agama merokok, 96,8\% disediakan rokok 
saat ada acara atau hajatan, 46,3\% masyarakat menganggap iklan rokok menarik, $100 \%$ teman merokok, dan $77,9 \%$ orang tua merokok.

Perilaku sebagai faktor penentu manusia merupakan resultansi dari berbagai faktor baik internal maupun eksternal. Faktor internal dalam hal ini adalah keyakinan, niat, percaya diri. Sedangkan faktor ekternal atau faktor lingkungan yaitu lingkungan fisik dan lingkungan sosial. Adapun faktor-faktor yang mempengaruhi perilaku merokok diantaranya:Pengaruh Orang Tua, pengaruh teman, factor kepribadian, pengaruh iklan. Perilaku merokok biasanya dimulai saat remaja dan berlanjut hingga dewasa. Orang tua sangat berpengaruh sekali dalam pembinaan perilaku anak-anaknya. Anak akan mudah terpengaruh untuk berperilaku merokok jika melihat orang tua mereka merokok. Anak yang berasal dari keluarga yang kurang bahagia, dimana orang tua tidak begitu memperhatikan anak-anaknya juga dapat memicu anak untuk berperilaku merokok, dibanding anak-anak yang berasal dari keluargayang bahagia.Pengaruh Teman; Semakin banyak anak-anak merokok maka semakin besar kemungkinan teman-temannya adalah perokok dengan alasan agar anak tersebut dapat diterima dilingkungannya dan tidak dikatakan benci oleh sebagian anak lainnya.Faktor Kepribadian; Perilaku merokok pada remaja berkaitan dengan adanya krisis aspek psikososial yang dialami pada masa perkembangannya, yaitu masa ketika mereka sedang mencari jati dirinya. Pengaruh Iklan; Anak akan mudah terpengaruh untuk berperilaku merokok jika melihat iklan di media massa dan elektronik yang menampilkan gambaran bahwa perokok adalah lambang kejantanan atau glamour(Halifah 2012).

Terdapat 4 tahap dalam perilaku merokok sehingga menjadi perokok yaitu :Tahap Preparatory; Seseorang mendapatkan gambaran yang menyenangkan mengenai perokok dengan cara mendengar, melihat atau dari hasil bacaan. yang menyebabkan minat untuk merokok. Tahap Innitiation;Tahap perintisan merokok yaitu tahap apakah seseorang akan meneruskan ataukah tidak terhadap perilaku merokok.Tahap becoming a smoker;Apabila seseorang telah mengkonsumsi rokok sebanyak 4 batang per hari maka mempunyai kecenderungan menjadi perokok.Tahap maintenance of smoking; tahap ini merokok sudah menjadi salah satu bagian dari cara pengaturan diri (self-regulating). Merokok dilakukan untuk memperoleh efek fisiologis yang menyenangkan(Halifah 2012). 


\section{Kesimpulan}

Perilaku masyarakat terhadap merokok tergolong tinggi dengan faktor Pemungkin (Enabling Factor) sebagian besar toko menjual rokok secara bebas, jarak rumah warga dengan toko penjual rokok. Faktor Penguat(Reinforcing Faktor) disebabkan karena teman merokok. tokoh masyarakat merokok, pemuka agama merokok, disediakan rokok saat ada acara (hajatan), orang tua merokok dan masyarakat menganggap iklan rokok menarik.

\section{Saran}

Diharapkan Dinas Kesehatan bersamapemerintah daerah setempat, tokoh agama dan tokoh masyarakat untuk melakukan FGD (Focus Group Discation)tentang aturan merokok dan tindaklajutnya jika tidak mengindahkan aturan dengan baik.

\section{Daftar Pustaka}

Alamsyah, Rika M. (2009). Faktor-Faktor yang Mempengaruhi Kebiasaan Merokok dan Hubungannya dengan Status Penyakit Periodontal Remaja di Kota Medan. Medan : Universitas Sumatera Utara.

Depkes. (2011). Lindungi Generasi Muda dari Bahaya Rokok. Online ... [Diakses tanggal 31 Maret 2018]. Available at: http://depkes.go.id/indeks.php/berita/press - release/1528 lindungi - generasi - muda - dari - bahaya - merokok.html

Halifah. (2012). Analisi Faktor yang Mempengaruhi Permintaan Rokok Masyarakat di Kota Makassar Tahun 2012. Skrips . Online ... [Diakses tanggal 31 Maret 2018]. Available at:

http://repository.unhas.ac.id/bitstream/handle/123456789/1824/HALIFAH_DAFTAR\% 20ISI.docx? sequence $=5$

Hanum, H., Wibowo, A. (2016). Pengaruh Paparan Asap Rokok Lingkungan pada Ibu Hamil terhadap Kejadian Berat Bayi Lahir Rendah : Majority Vol.5

Hayfaa AW,et al. Effects Of Secondhand Smoke On The Birth Weight Of Term Infants And The Demographic Profile Of Saudi Exposed Woman. BMC Public Health. (2013); 13(341):1471-2458.

Kemenkes RI. (2011). JakartaPedoman Pengembangan Kawasan Tanpa Rokok. Kemenkes RI. Jakarta

KemenkesRI. (2017) .Berhenti Merokok - Pasti Bisa ! Online ... [Diakses tanggal 31 Maret 2018]. Available at: http://www.depkes.go.id/development/site/depkes/pdf.php?id=117042500006 
Magdalena, C., et al. Tobacco Smoke Exposure During Pregnancy Increases Maternal Blood Lead Levels Affecting Neonate Birth Weight. Biol Trace Elem Res. 2013; 2(155):16975.

Oktavia, Dewi. (2011). Faktor - Faktor Yang Berhubungan Dengan Tindakan Merokok Siswa Laki - Laki Di SMA Negeri Kota Padang Tahun 2011.Skripsi. Padang : Program Studi Ilmu Kesehatan Masyarakat.

Sutrisno J, Syiska AM. Hubungan Ibu Hamil Sebagai Perokok Pasif Dengan Berat Badan Bayi Baru Lahir di RSD. Kalisat Kabupaten Jember Tahun 2013. Jurnal Kesehatan Dr. Soebandi. 2013; 2(1):51-8.

Syaifulloh, Novyan Hardar. 2013. Studi Peranan Tokoh Agama dan Perilaku Merokok Santri di Pondok Pesantren Al-Islah Desa Bandar Kidul Kecamatan Mojoroto Kota Kediri. Surabaya : Universitas Airlangga. 